Результаты исследования. Освещены анализ современного состояния и перспективы развития семеноводства в Украине и мире, предложены пути решения коммерческого оборота семян и посадочного материала. Намечены перспективные пути для ускорения развития организации рынка семян и посадочного материала Украины.

Элементы научной новизны. Получили дальнейшее развитие теоретические и методические положения по развитию семеноводства в Украине, которые предоставят возможность налаживания международного сотрудничества для выработки новых высокопродуктивных и качественных сортов отечественной селекции, что будет способствовать внедрению в растениеводство прогрессивных технологий и повышению производительности труда.

Практическая значимость. Решение указанных проблем даст возможность налаживания международного сотрудничества Украины по производству семян и посадочного материала и будет способствовать привлечению дополнительных инвестиционных средств на развитие селекционной отрасли. Табл.: 3. Илл.: 2. Библиогр.: 16.

Ключевые слова: семена и посадочный материал; эффективность производства; интеллектуальная собственность; система семеноводства; добазовое и базовое семеноводство.

Захарчук Александр Васильевич - доктор экономических наук, старший научный сотрудник, заведующий отделом инвестиционного и материально-технического обеспечения, Национальный научный центр «Институт аграрной экономики» (г. Киев, ул. Героев Обороны, 10)

E-mail: zahar-s@ukr.net

ORCID iD https://orcid.org/0000-0002-1734-1130

Стаття надійшла до редакції 09.03.2020 р.

Фахове рецензування: 12.03.2020 р.

Бібліографічний опис для цитування:

Захарчук О. В. Світовий ринок насіння та місце України в ньому. Економіка АПК. 2020. № 4. C. 16 - 26. https://doi.org/10.32317/2221-1055.202004016

Zakharchuk, O. V. (2020). Svitovyi rynok nasinnia ta mistse Ukrainy v nomu [The world seed market and the place of Ukraine in it]. Ekonomika APK, 4, pp. 16 - 26 [In Ukrainian]. https://doi.org/10.32317/2221-1055.202004016

УдК 330.3:631.1(477)

JEL Classification: Q14; Q12

DOI: https: / /doi.org/10.32317/2221-1055.202004026

Т.В. МАЦИБОРА, кандидат економічних наук, старший науковий співробітник

\title{
Тенденції розвитку інвестиційної діяльності в аграрному секторі економіки України
}

Мета статmі - встановити основні тенденції розвитку інвестиційної діяльності в аграрному секторі економіки України, визначити джерела фінансування капітальних інвестицій в сільському, лісовому та рибному господарстві й обгрунтувати їхні переваги і недоліки в сучасних умовах.

Методика дослідження. У процесі дослідження використано діалектичний метод наукового пізнання, аналізу й синтезу, системного узагальнення (встановлення основних тенденцій розвитку інвестиційної діяльності та визначення джерел фінансування капітальних інвестицій в аграрному секторі економіки України; формування висновків), аналітичне вирівнювання тренда (лінійне) (виявлення тенденції динаміки капітальних інвестицій в аграрному секторі).

Результати дослідження. Встановлено основні тенденції розвитку інвестиційної діяльності в аграрному секторі економіки України. Визначено джерела фінансування капітальних інвестицій в сільському, лісовому та рибному господарстві. Обгрунтовано переваги і недоліки джерел фінансування капітальних інвестицій в аграрному секторі економіки України в сучасних умовах.

Елементи наукової новизни. На основі встановлених основних тенденцій розвитку інвестиційної діяльності в аграрному секторі та детального аналізу джерел ії фінансування, обгрунтовано переваги та недоліки кожного з них та розроблено пропозиції щодо напрямів і джерел фінансування інвестицій з метою формування сприятливого середовища для забезпечення інклюзивного розвитку сільського господарства та сільських територій.

() Т.В. Мацибора, 2020 
Практична значущість. Висновки, пропозиції та практичні рекомендації можуть бути використані при формуванні інвестиційних програм і проєктів у сільському господарстві та розробці державних програм розвитку аграрного сектору економіки України. Рис.: 4. Бібліогр.: 14.

Ключові слова: інвестиції; капітальні інвестиції; інвестиційна діяльність; інвестиційний тренд; лінійний тренд; джерела фінансування капітальних інвестицій; аграрний сектор.

Мацибора Тетяна Вікторівна - кандидат економічних наук, старший науковий співробітник, провідний науковий співробітник відділу інвестиційного та матеріально-технічного забезпечення, Національний науковий центр «Інститут аграрної економіки» (м. Київ, вул. Героїв Оборони, 10)

E-mail: tatyk@ukr.net

Постановка проблеми. Інвестиції становлять важливу складову економічного зростання та розвитку як окремих галузей, так $\mathrm{i}$ країни в цілому. Забезпечення позитивної інвестиційної динаміки в аграрному секторі являє собою необхідну умову досягнення продовольчої і національної безпеки країни та економічного зростання і розвитку в майбутньому.

Сільському господарству України притаманні значні конкурентні переваги на світових ринках, потужний, проте повністю не розкритий потенціал, це один із найбільш привабливих для інвесторів секторів економіки, тому має всі передумови для подальшого розвитку. Водночас у сучасних умовах на фоні падіння обсягів промислового виробництва та за рахунок експортної орієнтованості сільське господарство відіграє роль своєрідного каталізатора економічного зростання країни. Тому важливе створення сприятливого середовища та умов для розвитку національного аграрного сектору через розширення його інвестиційного потенціалу, стимулювання інвестиційної діяльності сільськогосподарських товаровиробників та забезпечення позитивної динаміки капітальних інвестицій.

Аналіз останніх досліджень і публікацій. Проблеми розвитку аграрного сектору економіки, його інвестиційного забезпечення та джерел фінансування капітальних інвестицій досліджувалися й висвітлені у працях відомих вітчизняних і зарубіжних учених, серед яких М. Брейді, Р. Конг [11]; К. Бутс, М. Джегерс [10]; В. Вадхо, А. Умаїр [14]; Н. Гражевська [12]; С. Дем'яненко, А. Кузнєцова [2]; О. Захарчук [3, 4]; М. Кропивко [5]; Ю. Лупенко [4, 5]; Г. Савицька [8]; А. Тарасенко, Д. Яблонський [9].

Мета статті - встановити основні тенденції розвитку інвестиційної діяльності в аграрному секторі економіки України, визначити джерела фінансування капітальних інвестицій в сільському, лісовому та рибному господарстві й обґрунтувати їхні переваги і недоліки в сучасних умовах.
Виклад основних результатів дослідження. Аграрному сектору належить особливе місце в економіці нашої країни. Нині він визнаний однією з точок зростання національної економіки. У структурі валового внутрішнього продукту його частка становить 10-12 \%. Вітчизняна продукція сільського господарства та безпосередньо пов'язаних із ним секторів економіки характеризується стабільним попитом на світових ринках. Близько 40 \% експортованих товарів - сільськогосподарська продукція та продукція харчової промисловості.

Протягом 2010-2018рр. спостерігається позитивна тенденція щодо збільшення частки інвестицій у сільське, лісове та рибне господарство у загальному обсязі капітальних інвестицій в економіку України, що, зважаючи на провідну роль національного аграрного сектору, цілком природно. Максимального значення цей показник досяг у 20162017 рр. (відповідно 14,1 і 14,3 \%), що удвічі більше порівняно з 2010-2013 рр. (рис. 1).

Як засвідчує динаміка капітальних інвестицій в аграрному секторі, їхні обсяги за період з 2010-го по 2018 р. відзначаються тенденцією до зростання. Позитивний тренд дещо уповільнився через різке скорочення обсягів капітальних вкладень у 20142015 рр., коли розпочалася російська збройна агресія проти України. I лише у 20172018 рр. обсяги капітальних інвестицій вперше перевищили розміри капітальних вкладень зазначених років.

Діяльність іноземних інвесторів в аграрному секторі нині малоактивна, що вказує на погіршення інвестиційного клімату в Україні. Починаючи з 2014 р. обсяги залучення прямих іноземних інвестицій помітно скорочуються. Стійка тенденція до відтоку іноземного капіталу зумовлена насамперед високими додатковими ризиками (політичними, економічними, валютними тощо). Внаслідок тривалої спадної динаміки обсяги прямих іноземних інвестицій у 2018 р. порівняно 3 2010 р. зменшилися майже на чверть. 


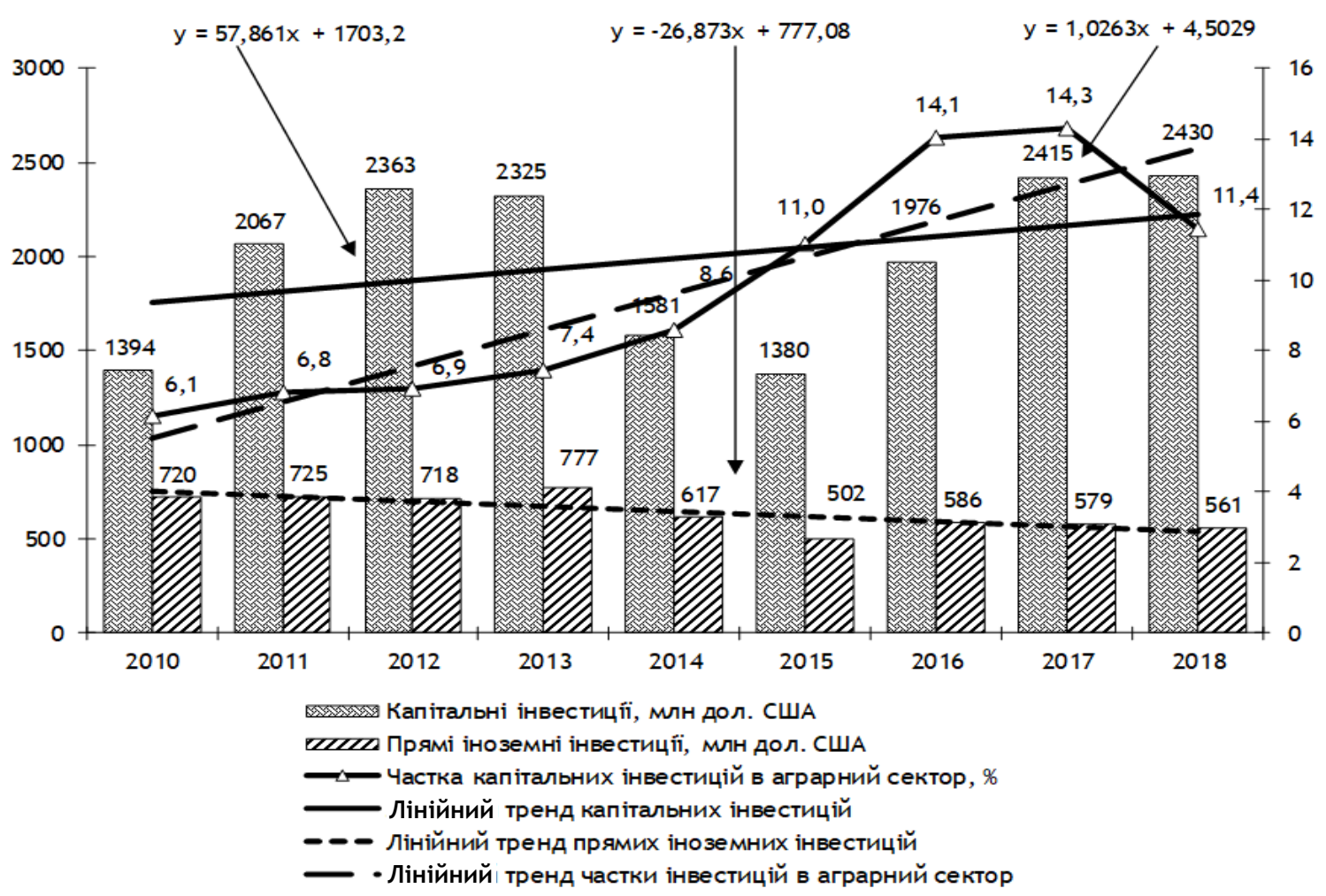

Рис. 1. Інвестиційна діяльність в аграрному секторі економіки, 2010-2018 рр.

Джерело: Побудовано за даними Державної служби статистики України. URL : http:/ /www.ukrstat.gov.ua.

Основним джерелом фінансування капітальних інвестицій в аграрному секторі залишаються власні кошти підприємств, за рахунок яких у 2018 р. освоєно 86,8 \% капітальних вкладень (рис. 2). Однак для переважної більшості малих і середніх підприємств аграрного сектору внутрішні джерела фінансу- вання інвестицій, серед яких передусім прибуток та амортизаційні відрахування, не в змозі забезпечити розширене відтворення процесу виробництва. У 2018 р. серед малих і середніх підприємств частка збиткових становила відповідно 13,8 i $11,5 \%$, тоді як усі великі підприємства були прибутковими.

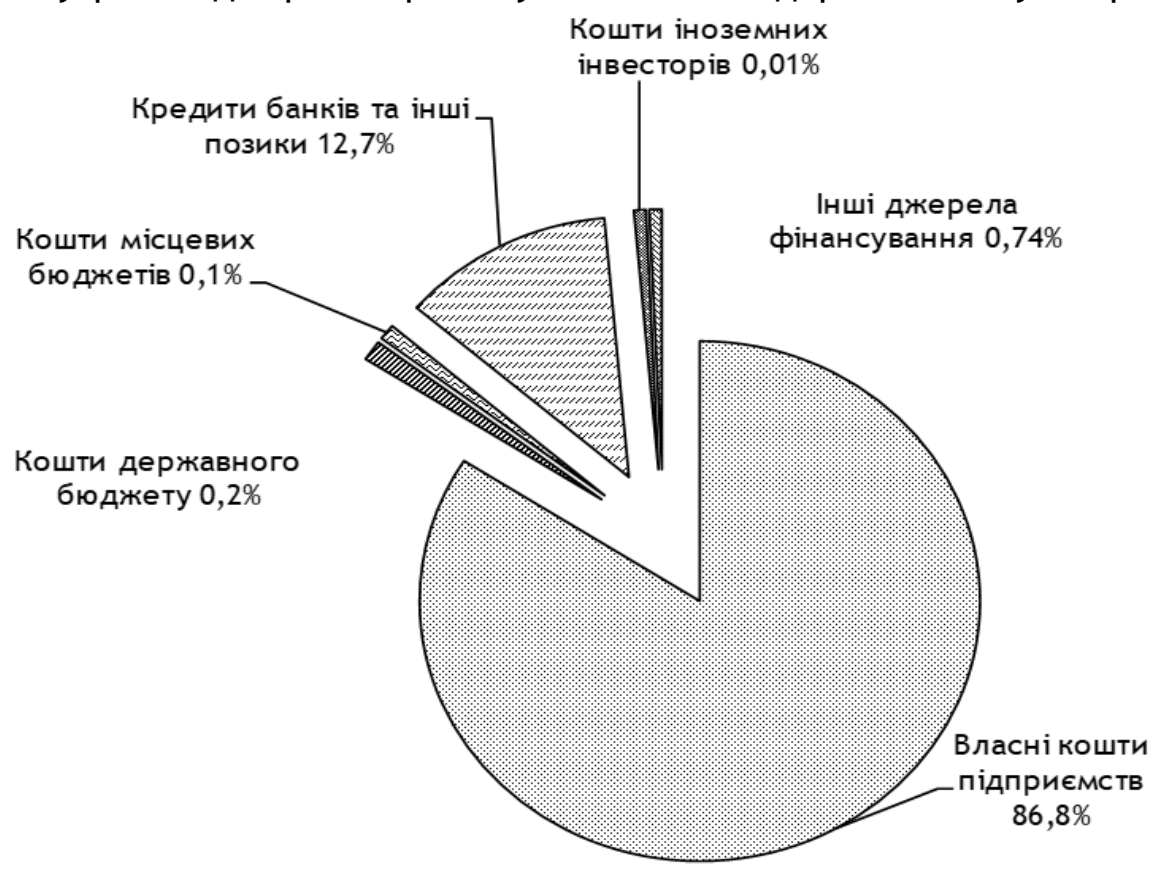

Рис. 2. Джерела фінансування капітальних інвестицій у сільському, лісовому та рибному господарстві, 2018 р.

Джерело: Побудовано за даними Державної служби статистики України. URL : http://www.ukrstat.gov.ua. 
За дослідженнями О. Захарчука, матеріально-технічне забезпечення підприємств різних форм господарювання знаходиться на неналежному рівні. Серед основних причин недостатність коштів у підприємств малих і середніх форм господарювання, недосконалість кредитної та амортизаційної політики, недостатня державна підтримка [3, с. 50].

Серед залучених джерел фінансування інвестицій іноземний капітал зазвичай тісно пов'язується із впровадженням інновацій, нових технологій, знань та методів організації виробництва і бізнесу, які виступають прискорювачами економічного зростання та розвитку. В сучасний період іноземні інвестиції не відіграють значної ролі в інвестиційному забезпеченні національного аграрного сектору. На кошти іноземних інвесторів у 2018 р. припадало лише 0,01 \% усіх капітальних вкладень у сільському, лісовому та рибному господарстві. Водночас понад 40 \% обсягу прямих іноземних інвестицій надійшло з офшорних зон, у зв'язку з чим наявні підстави стверджувати про його українське походження.

За результатами дослідження, проведеного інвестиційною компанією Dragon Capital, Європейською Бізнес Асоціацією (ЄБА) та Центром економічної стратегії (ЦЕС) у квітні 2019 р., основними перешкодами для іноземних інвестицій уже четвертий рік поспіль визначено наступні: масова корупція; недовіра до судової системи; монополізація ринків; збройний конфлікт із Росією; репресивні дії правоохоронних органів; нестабільна валюта та фінансові ринки [7].

Іншим джерелом інвестицій для сільськогосподарських товаровиробників може бути фінансування з державного та місцевих бюджетів. Відповідно до Закону України «Про державну підтримку сільського господарства України» держава декларує можливість таких видів підтримки [6]: фінансова підтримка суб'єктів господарювання агропромислового комплексу через механізм здешевлення кредитів та компенсацію лізингових платежів (ст. 13.1); бюджетна тваринницька дотація (ст. 15); бюджетна дотація для розвитку сільськогосподарських товаровиробників та стимулювання виробництва сільськогосподарської продукції (ст. 16-1); інші види державної підтримки сільськогосподарських товаровиробників (ст. 17-2).

Згідно зі ст. 15.1 цього Закону бюджетна тваринницька дотація надається з метою під- тримки рівня платоспроможного попиту українських споживачів продукції тваринництва та запобігання виникненню збитковості українських виробників такої продукції.

У 2018 р. за рахунок коштів державного i місцевих бюджетів у сільському, лісовому та рибному господарстві освоєно лише 0,3 \% капітальних інвестицій, тоді як капітальні інвестиції за рахунок бюджетних коштів в економіку загалом у 2018 р. становили 12,6 \%.

Використання державної підтримки може бути корисним для держави, але не завжди сприяє економічній ефективності. Як свідчать емпіричні дослідження, розподіл субсидій залежно від поголів'я худоби або від обсягу виробництва призводить до збільшення ринкової концентрації [10] та додаткових експортних переваг, адже більші виробники все одно одержать вагомішу підтримку за рахунок недофінансування менших виробників [11].

За оцінками багатьох дослідників, бюджетна підтримка аграрного сектору не завжди відповідає інтересам споживачів, не сприяє інклюзивному розвитку сільського господарства, здебільшого не зменшує ризики для виробників малого і середнього бізнесу, посилює лобіювання інтересів великого бізнесу, корупцію та монополізм в окремих галузях.

Малі господарства виграють за рахунок того, що додаткове фінансування допомагає покрити сезонні потреби у ліквідних коштах. Проте найбільше від субсидій виграють великі агрохолдинги та постачальники ресурсів [9, с. 14]. Водночас агрохолдинги витісняють 3 аграрного бізнесу традиційні форми ведення сільськогосподарського виробництва аграрні підприємства і фермерські господарства, що органічно поєднані з сільською місцевістю, іiі інфраструктурою, адже їхні власники та менеджери, як правило, там і проживають [2, с. 15].

У 2018 р. агроіндустріальний холдинг ПрАТ «Миронівський хлібопродукт» (бренд «Наша Ряба») одержав найбільшу підтримку - близько 970 млн грн державної допомоги, що становить чверть від усієї фактично наданої аграрному сектору допомоги. Також із державного бюджету було виділено допомогу в розмірі 3,5 млн грн ТОВ «УкраАгроКом» [1] - компанії, яка займається продажем добрив, засобів захисту рослин та насіння. Загалом постачальники засобів виробництва - це найбільші реципієнти програм дер- 
жавної підтримки аграрного сектору. Зокрема, вони одержують понад $80 \%$ дотацій 3 державного бюджету.

За причину подібного нераціонального розподілу субсидій слугує «пошук ренти» з боку великих агрохолдингів [9, с. 15]. Негативний вплив такого виду державної підтримки підтверджено емпіричними дослідженнями. При цьому встановлено, що пошук ренти знижує ефективність фіскальної системи країни [12] і чим лояльніша держава до такої поведінки, тим нижчі темпи економічного зростання її очікують [14].

Недостатня забезпеченість інвестиційними ресурсами малого і середнього агробізнесу та іхні неоднакові можливості в доступі до зовнішніх джерел фінансування інвестицій порівняно з великими підприємствами спричиняють економічну нерівність організаційно-правових форм у сільському господарстві, унеможливлюють інклюзивний розвиток сільської економіки, загострюють проблеми на ринку праці в сільській місцевості, посилюють міграційні процеси та обезлюднення сільських територій.

За дослідженнями Ю. Лупенка і М. Кропивка, діяльність аграрних холдингових формувань призводить до зростання соціальної напруги на селі, вимивання коштів із сільських територій, у тому числі внаслідок: розвитку монополізації, перерозподілу власності та зменшення життєвого простору для діяльності інших організаційно-правових форм господарювання на землі; загострення соціальних проблем на селі через звільнення працівників і зростання безробіття; поглиблення дисбалансу галузевої структури сільськогосподарського виробництва і нераціонального використання землі; недостатньої участі у формуванні місцевих бюджетів, розвитку сільських громад і територій; неналежного суспільного контролю за їх діяльністю [5, с. 18-19].

Використання позикового капіталу як джерела інвестицій, хоча й підвищує фінансовий ризик та зменшує прибутковість сукупних активів через виплати відсотків по позиках, за умов ефективного використання капіталу позитивно впливає на інвестиційну активність і дохідність підприємства.

Якщо підприємство здатне забезпечити вищий рівень віддачі на вкладений капітал, ніж платить за кредитні ресурси, то, залучаючи позикові кошти, воно може контролювати більші грошові потоки, розширювати масштаби своєї діяльності, підвищувати рентабельність власного капіталу, зміцнювати ринкові позиції [8, с. 455].

На кредити банків та інші позики в загальних обсягах капітальних інвестицій у 2018 р. припадало 12,7 \%. Одним з основних чинників, що стримують розширення використання позикового капіталу, слід вказати високу вартість кредитних ресурсів. Кредитні ставки в Україні значно вищі, ніж у Європі, що негативно впливає на рівень кредитування аграрного сектору. Так, обсяги кредитування сільського господарства у Німеччині і Франції в 2010-2018 рр. були більші порівняно з Україною у 12-14 разів (рис. 3).

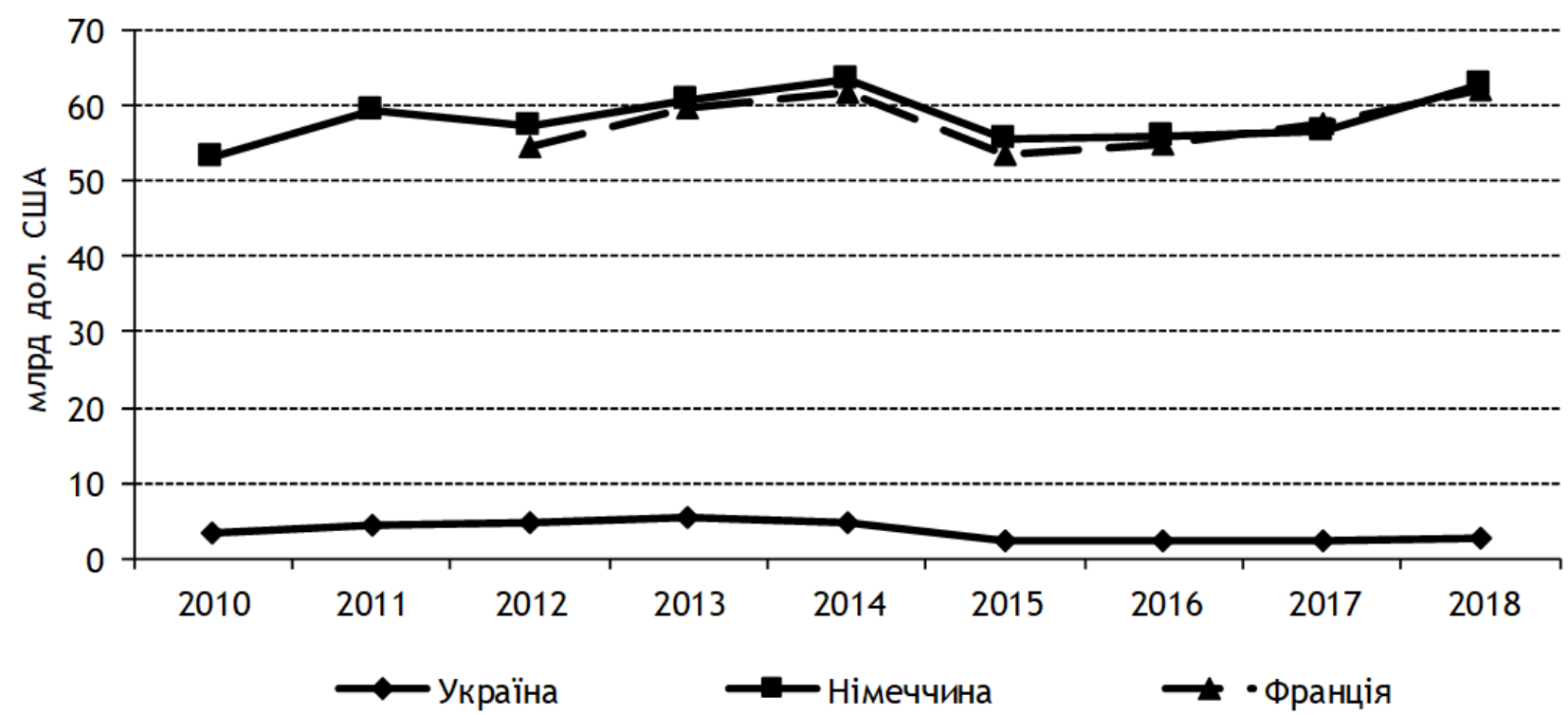

Рис. 3. Кредитування аграрного сектору в Україні, Німеччині та Франції, 2010-2018 рр.

Джерело: Побудовано за даними: Національного банку України. URL : http://www.bank.gov.ua; Продовольчої та сільськогосподарської організації ООН (ФАО). URL : http://www.fao.org. 
За даними Міжнародної фінансової корпорації (IFC), переважна більшість українських сільськогосподарських підприємств вважають обмежений доступ до кредитів головним бар'єром для нарощування обсягів аграрного виробництва, а $60 \%$ підприємств не мають доступу до залучення ресурсів [13].

Проаналізувавши динаміку капітальних інвестицій, здійснених за рахунок кредитів банків та інших позик, варто зауважити, що їхні обсяги за період з 2010-го по 2018 р. мали тенденцію до зменшення. Різкий спад відбувся після 2013 р. У 2014 р. обсяги капітальних інвестицій в аграрному секторі, здійснені за рахунок банківських кредитів, скоротилися майже удвічі порівняно з попереднім роком. Лише у 2018 р. обсяги кредитування сільськогосподарських підприємств майже досягли рівня 2010 р. ( рис. 4).

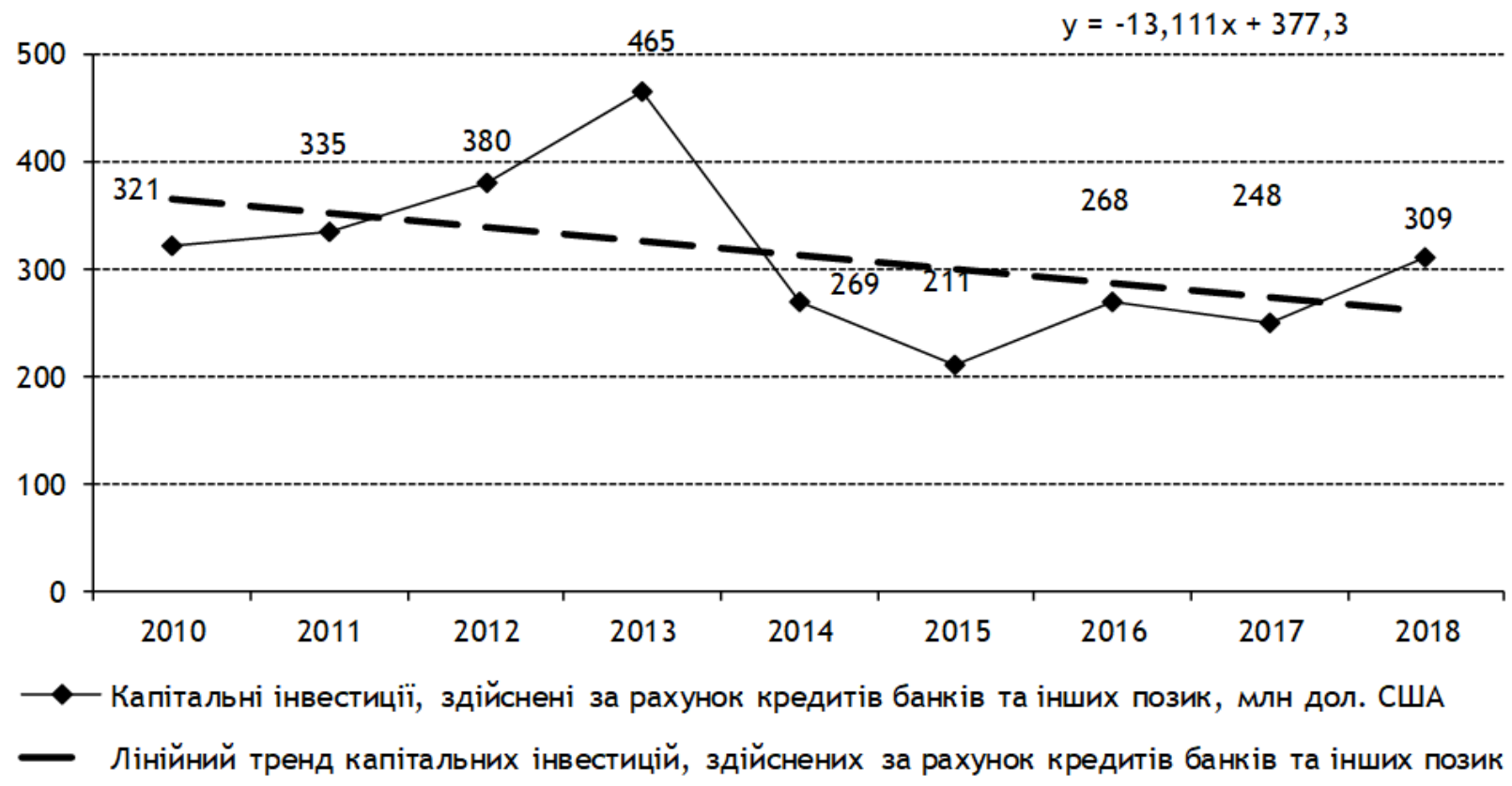

Рис. 4. Динаміка капітальних інвестицій в аграрному секторі, здійснених за рахунок кредитів банків та інших позик

Джерело: Побудовано за даними: Державної служби статистики України. URL : www.ukrstat.gov.ua]; Міністерства аграрної політики та продовольства України. URL : agro.me.gov.ua.

Таким чином, з одного боку, спостерігається хоча й не значна, проте позитивна динаміка щодо нарощування обсягів капітальних інвестицій в аграрному секторі, з іншого - суттєве скорочення обсягів кредитування сільськогосподарських підприємств, що звужує їхній виробничий потенціал, обмежує реалізацію потенційних можливостей, гальмує розвиток. Така ситуація зумовлена не лише недосконалістю фінансово-кредитної системи, нестабільністю та несприятливими економічними умовами, а й специфічними особливостями сільськогосподарського виробництва, які передбачають існування додаткових ризиків як суб'єктивного, так i об'єктивного характеру.

Висновки. Забезпечення стійкої позитивної динаміки капітальних інвестицій виступає важливою умовою економічного зростання та розвитку національного аграрного сектору. Незважаючи на в цілому позитивну динаміку щодо нарощування капітальних інвестицій сільськогосподарськими товаровиробниками, в 2014-2015 рр. спостерігається різке скорочення обсягів капітальних вкладень через російську збройну агресію проти України. Подолати падіння вдалося у 2016 р. і лише у 2017-2018 рр. обсяги капітальних інвестицій вперше перевищили розміри капітальних вкладень зазначених років.

Унаслідок погіршення інвестиційного клімату в Україні простежується стійка тенденція до відтоку іноземного капіталу. За тривалої спадної динаміки обсяги прямих іноземних інвестицій у 2018 р. порівняно з 2010 р. зменшилися майже на чверть.

Основним джерелом фінансування капітальних інвестицій в аграрному секторі залишаються власні кошти підприємств, за рахунок яких освоюється близько 87 \% капітальних вкладень. Більшість підприємств малого i середнього агробізнесу потребують залучення фінансових ресурсів, оскільки власних 
коштів недостатньо для забезпечення розширеного відтворення процесу виробництва.

Динаміка капітальних інвестицій, здійснених за рахунок кредитів банків та інших позик за період з 2010-го по 2018 р., мала спадну тенденцію. Різкий спад кредитування сільськогосподарських товаровиробників спостерігається у 2014 р., коли обсяги капітальних інвестицій, здійснені за рахунок банківських кредитів, скоротилися мало не вдвічі порівняно з попереднім роком. Лише у 2018 р. обсяги кредитування сільськогосподарських підприємств майже досягли рівня 2010 р.

Більшість підприємств малого і середнього агробізнесу мають обмежений доступ до кредитних ресурсів. Як один з основних чинників, що стримують розширення використання позикового капіталу, слід вказати високу вартість кредитних ресурсів. Кредитні ставки в Україні значно вищі ніж у Європі, отже обсяги кредитування національного

\section{Список бібліографічних посилань}

1. Аграрні мільйони: куди і навіщо спрямовують дотації на сільське господарство. URL : https://24tv.ua/ agrarni_milyoni_kudi_i_navishho_spryamovuyut_dotatsiyi_na_ silske gospodarstvo_n1111765 (дата звернення: 16.04.2020).

2. Дем'яненко С. І., Кузнєцова А. В. Агрохолдинги в Україні: добре чи погано? : Серія консультативних робіт. Київ : Німецько-український аграрний діалог ; Інститут економічних досліджень та політичних консультацій, 2008. 20 с.

3. Захарчук О. В. Технічне забезпечення сільськогосподарських підприємств в Україні. Економіка АПК. 2019. № 2. С. 48-56.

4. Лупенко Ю. О., Захарчук О. В. Інвестиційне забезпечення інноваційного розвитку сільського господарства України. Економіка АПК. 2018. № 11. С. 9-18.

5. Лупенко Ю. О., Кропивко М. Ф. Агрохолдинги в Україні та посилення соціальної спрямованості їх діяльності. Економіка АПК. 2013. № 7. С. 5-21.

6. Про державну підтримку сільського господарства України : Закон України від 24.06.2004 N 1877-IV (зі змінами). База даних «Законодавство України» / Верховна Рада України. URL : https://zakon.help/law/1877-IV/edition15.08.2018 (дата звернення: 16.04.2020).

7. Регулярне опитування іноземних інвесторів: Спеціальний випуск (квітень 2019 р.) Київ : Центр економічної стратегії, 20018. 20 c. URL : https://ces.org.ua/ (дата звернення: 16.04.2020).

8. Савицька Г. В. Економічний аналіз діяльності підприємства : навчальний посібник. Київ : Знання, 2005. 662 с.

9. Тарасенко А., Яблонський Д. Яка модель субсидіювання аграрного сектора потрібна Україні (30 жовтня 2018 р.). Київ : Центр економічної стратегї̈, 20018. 24 с. URL : https://ces.org.ua/ (дата звернення: 16.04.2020).

10. Buts $C$., Jegers $M$. The effect of subsidies on the evolution of market structure. Brussel. 2008. 19 p. URL : http://www.stateaid.gr/ images/article-attachments/The_effect_of_SA_on_competi-

tion_Cresse.pdf (дата звернення: 16.04.2020).

11. Cong, R., Brady, M. How to Design a Targeted Agricultural Subsidy System: Efficiency or Equity? 2012. PLoS ONE, № 7(8). 12 p. e41225. https://doi.org/10.1371/journal.pone.0041225 (дата звернення: 16.04.2020).

12. Grazhevska, N. et al. The Effects of Rent-Seeking Behavior on the Efficiency of Fiscal Policy in Ukraine. Procedia Economics and Finance. 2015. Vol. 27. Pp. 274-287. сільського господарства на порядок менші порівняно з європейськими.

Бюджетна підтримка аграрного сектору зазвичай не відповідає інтересам українських споживачів та не сприяє інклюзивному розвитку сільського господарства, оскільки основні реципієнти бюджетних коштів, виділених на підтримку аграрного сектору, це великі агрохолдинги та постачальники засобів виробництва і ресурсів.

Недостатня забезпеченість інвестиційними ресурсами малих і середніх сільськогосподарських підприємств та їхні неоднакові можливості у доступі до зовнішніх джерел фінансування інвестицій порівняно з потужними аграрними корпораціями спричиняють економічну нерівність організаційно-правових форм у сільському господарстві, унеможливлюють інклюзивний розвиток сільської економіки, загострюють проблеми на ринку праці в сільській місцевості, посилюють міграційні процеси та обезлюднення сільських територій.

\section{References}

1. Ahrarni miliony: kudy i navishcho spriamovuiut dotatsii na silske hospodarstvo [The agrarian millions: where and why the directed subsidies to agriculture]. Retrieved from: https://24tv.ua/agrarni_milyoni_kudi_i_navishho_spryamovuyut_ dotatsiyi_na_silske_gospodarstvo_n1111765 [In Ukrainian].

2. Demianenko, S.I., Kuznietsova, A.V. (2008). Ahrokholdynhy $v$ Ukraini: dobre chy pohano? : Seriia konsultatyvnykh robit [The agroholdings in Ukraine: good or bad? : Advisory Series]. Kyiv: Nimetsko-Ukrainskyi Ahrarnyi Dialoh; Instytut ekonomichnykh doslidzhen ta politychnykh konsultatsii [In Ukrainian].

3. Zakharchuk, O.V. (2019). Tekhnichne zabezpechennia silskohospodarskykh pidpryiemstv v Ukraini [Technical maintenance of agricultural enterprises in Ukraine]. Ekonomika APK, 2, pp. 48-56. [In Ukrainian].

4. Lupenko, Yu.O., Zakharchuk, O.V. (2018). Investytsiine zabezpechennia innovatsiinoho rozvytku silskoho hospodarstva Ukrainy [Investment provision of innovative development of Ukrainian agriculture]. Ekonomika APK, 11. pp. 9-18. [In Ukrainian].

5. Lupenko, Yu.O., Kropyvko, M.F. (2013). Ahrokholdynhy v Ukraini ta posylennia sotsialnoi spriamovanosti yikh diialnosti [Agroholdings in Ukraine and strengthening of social orientation of their activity]. Ekonomika APK, 7, pp. 5-21 [In Ukrainian].

6. Pro derzhavnu pidtrymku silskoho hospodarstva Ukrainy : Zakon Ukrainy vid 24.06.2004 \# 1877-IV (zi zminamy) [On public procurements: 24.06.2004, № 1877-IV (with changes)]. Baza danykh "Zakonodavstvo Ukrainy". VR Ukrainy. Retrieved from: https://zakon.help/law/1877-IV/edition15.08.2018 [In Ukrainian].

7. Rehuliarne opytuvannia inozemnykh investoriv: Spetsialnyi vypusk (kviten 2019 r.) [Regular survey of foreign investors: Special issue (April 2019)] Kyiv: Tsentr ekonomichnoi stratehii. Retrieved from: https://ces.org.ua/ [In Ukrainian].

8. Savytska, H.V. (2005). Ekonomichnyi analiz diialnosti pidpryiemstva: Navch. posib. [Economic analysis of the enterprise: teach. guidances]. Kyiv: Znannia [In Ukrainian].

9. Tarasenko, A., Yablonskyi, D. (2018). Yaka model subsydiiuvannia ahrarnoho sektora potribna Ukraini (30 zhovtnia 2018 r.) [Which model of agricultural sector support does Ukraine need? (October 30, 2018)]. Kyiv: Tsentr ekonomichnoi stratehii. Retrieved from: https://ces.org.ua/ [In Ukrainian]. 
13. IFC (2011). Investment Climate in Ukraine as Seen by Private Business, IFC Ukraine Investment Climate Project Report. URL : https://www.ifc.org/wps/wcm/connect/facbbf804b8692d9bf19bf6eac26e1c2/Ukraine-IC-Report_Nov2011_ ENG.pdf?MOD=AJPERES\&CACHEID=facbbf804b8692d9bf19bf6eac26e1c2 (дата звернення: 16.04.2020).

14. Wadho W., Umair A. Government size and economic growth in an endogenous growth model with rent-seeking. Economics \& Politics. 2017. Vol. 30, no. 1. Pp. 151-179.
10. Buts, C. and Jegers, M. (2008). The effect of subsidies on the evolution of market structure. Brussel. Retrieved from: http://www.stateaid.gr/ images/article-attachments/ The_effect_of_SA_on_competition_Cresse.pdf. [In English].

11. Cong, R. \& Brady, M. (2012). How to Design a Targeted Agricultural Subsidy System: Efficiency or Equity? PLoS ONE, 7(8). Retrieved from: e41225. doi:10.1371/journal.pone.0041225. [In English].

12. Grazhevska, N., et al. (2015). The Effects of Rent-Seeking Behavior on the Efficiency of Fiscal Policy in Ukraine. Procedia Economics and Finance, vol. 27 [In English].

13. IFC (2011). Investment Climate in Ukraine as Seen by Private Business, IFC Ukraine Investment Climate Project Report. Retrieved from: https://www.ifc.org/wps/wcm/connect/facbbf804b8692d9bf19bf6eac26e1c2/Ukraine-IC-Report_Nov2011_ENG. pdf?MOD=AJPERES\&CACHEID=facbbf804b8692d9bf19bf6eac26e1c2 [ [n English].

14. Wadho, W. \& Umair, A. (2017). Government size and economic growth in an endogenous growth model with rent-seeking. Economics \& Politics, 30 (1), pp. 151-179 [In English].

\section{Matsybora T.V. Trends of the investment activities development in the agrarian sector of economy of Ukraine}

The purpose of the article is to determine the main trends of the investment activity development in the agrarian sector of economy of Ukraine, to determine sources of financing of capital investments in agriculture, forestry and fisheries and to substantiate their advantages and disadvantages in the present conditions.

Research methods. Methods: dialectical method of scientific cognition, analysis and synthesis, systemic generalization (determination of the main trends of the investment activity development in the agrarian sector of economy of Ukraine; the formation of conclusions), analytical trend equalization (linear) (determining the dynamics trend of capital investment in the agricultural sector).

Research results. The main tendencies of development of investment activity in agrarian sector of economy of Ukraine are established. The sources of financing of capital investments in agriculture, forestry and fisheries are identified. It substantiated the advantages and disadvantages of sources of financing of capital investments in the agrarian sector of the Ukrainian economy in the current conditions. The advantages and disadvantages of sources of financing of capital investments in the agrarian sector of economy of Ukraine are reasoned in the present conditions

Scientific novelty. Based on the establishing of the main tendencies of development of investment activity in the agrarian sector and detailed analysis of sources of its financing, the advantages and disadvantages of each of them are substantiated and proposals for directions and sources of financing of investments in order to create a favorable environment for ensuring inclusive development of agriculture and rural territories are designed.

Practical significance. Conclusions, suggestions and practical recommendations can be used in the formation of investment programs and projects in agriculture and the development of state programs for the development of the agricultural sector of the economy of Ukraine. Figs.: 4. Refs.: 14.

Keywords: investments; capital investments; investment activity; investment trend; linear trend; sources of capital investment financing; agrarian sector.

Matsybora Tetiana Viktorivna - candidate of economic sciences, senior researcher fellow, leading research fellow of the department of investment, material and technical support, National Scientific Centre "Institute of Agrarian Economy" (10, Heroiv Oborony St., Kyiv)

E-mail: tatyk@ukr.net

\section{Мацибора Т.В. Тенденции развития инвестиционной деятельности в аграрном секторе экономики Украины}

Цель статьи - установить основные тенденции развития инвестиционной деятельности в аграрном секторе экономики Украины, определить источники финансирования капитальных инвестиций в сельском, лесном и рыбном хозяйстве и обосновать их преимущества и недостатки в современных условиях.

Методика исследования. В процессе исследования использованы диалектический метод научного познания, анализа и синтеза, системного обобщения (установление основных тенденций развития инвестиционной деятельности и определение источников финансирования капитальных инвестиций в аграрном секторе экономики Украины; формирование выводов), аналитическое выравнивание тренда (линейное) (выявление тенденции динамики капитальных инвестиций в аграрном секторе).

Результаты исследования. Установлены основные тенденции развития инвестиционной деятельности в аграрном секторе экономики Украины. Определены источники финансирования капитальных инвестиций в сельском, лесном и рыбном хозяйстве. Обоснованы преимущества и недостатки источников финансирования капитальных инвестиций в аграрном секторе экономики Украины в современных условиях.

Элементы научной новизны. На основе установленных основных тенденций развития инвестиционной деятельности в аграрном секторе и детального анализа источников ее финансирования, обоснованы преимущества и недостатки каждого из них и разработаны предложения относительно направлений и источников финансирования инвестиций с целью формирования благоприятной среды для обеспечения инклюзивного развития сельского хозяйства и сельских территорий.

Практическая значимость. Выводы, предложения и практические рекомендации могут быть использованы при формировании инвестиционных программ и проектов в сельском хозяйстве и разработке государственных программ развития аграрного сектора экономики Украины. Илл.: 4. Библиогр.: 14.

Ключевые слова: инвестиции; капитальные инвестиции; инвестиционная деятельность; инвестиционный тренд; линейный тренд; источники финансирования капитальных инвестиций; аграрный сектор. 
Мацибора Татьяна Викторовна - кандидат экономических наук, старший научный сотрудник, ведущий научный сотрудник отдела инвестиционного и материально-технического обеспечения, Национальный научный центр «Институт аграрной экономики» (г. Киев, ул. Героев Обороны, 10)

E-mail: tatyk@ukr.net

Стаття надійшла до редакції 08.04.2020 р.

Фахове рецензування: 12.04.2020 р.

Бібліографічний опис для цитування:

Мацибора Т. В. Тенденції розвитку інвестиційної діяльності в аграрному секторі економіки України. Економіка АПК. 2020. № 4. С. 26 - 34. https://doi.org/10.32317/2221-1055.202004026

Matsybora, T. V. (2020). Tendentsii rozvytku investytsiinoi diialnosti v ahrarnomu sektori ekonomiky Ukrainy [Trends of the investment activities development in the agrarian sector of economy of Ukraine]. Ekonomika APK, 4, pp. 26 - 34 [In Ukrainian]. https://doi.org/10.32317/2221-1055.202004026

УДК 339.137.2:637.12:332.1

JEL Classification: D24; R11

DOI: https: / / doi.org/10.32317/2221-1055.202004034

О.А. КОЗАК, кандидат економічних наук, старший науковий співробітник

О.Ю. ГРИЩЕНКО

\title{
Оцінювання регіональної конкурентоспроможності виробництва молока в Україні
}

\begin{abstract}
Mета статmi - розробити методичні підходи до оцінювання регіональної конкурентоспроможності виробництва молока в Україні, розрахувати інтегральні показники конкурентоспроможності по кожному регіону та на основі їх побудувати рейтинги, а також встановити залежність між конкурентоспроможністю виробництва та рівнем самозабезпеченості регіону молоком.

Методика дослідження. Робота грунтується на діалектичному методі пізнання з використанням таких методів дослідження: абстрактно-логічний (для узагальнення та формулювання висновків); порівняльного аналізу (для зіставлення рівня показників конкурентоспроможності виробництва молока між регіонами); статистико-економічний (при здійсненні рейтингової оцінки регіональної конкурентоспроможності виробництва молока); графічний (для наочного відображення результатів статистичного аналізу); балансовий (при визначенні співвідношення регіонального рівня виробництва та споживання молока), а також системний підхід, методи аналізу і синтезу, індукції і дедукції та інші у сфері економічних досліджень.

Результати дослідження. Розроблено методичні підходи до оцінки регіональної конкурентоспроможності виробництва молока, які представлені у вигляді послідовності наступних дій: визначити систему показників для оцінки конкурентоспроможності за основними виробниками молока; здійснити нормування середніх показників; розрахувати інтегральні індекси за кожним товаровиробником та визначити інтегральну рейтингову оцінку кожного регіону; побудувати рейтинг регіонів за інтегральними індексами та загальною рейтинговою оцінкою. Розрахунки, проведені згідно із зазначеним алгоритмом, дозволили визначити конкурентоспроможні регіони України за виробництвом молока.

Елементи наукової новизни. Набули подальшого розвитку методичні підходи до визначення рівня конкурентоспроможності виробництва молока в регіонах України з урахуванням усіх категорій товаровиробників та розрахунком співвідношення ступеня конкурентоспроможності регіону.

Практична значущість. Розроблені методичні підходи та результати оцінки є інформаційною базою для прийняття управлінських рішень, направлених на вирівнювання конкурентоспроможності виробництва молока в регіонах України в контексті розробки регіональної політики соціально-економічного розвитку. Отримані показники рівня конкурентоспроможності можуть бути використані сільськогосподарськими товаровиробниками для виявлення сильних чи слабких сторін у розвитку молочного виробництва та порівняння підприємства з успішнішими практиками господарювання. Інформація, отримана в дослідженні, буде цікавою потенційним інвесторам, які планують займатися молочним бізнесом в Україні. Табл.: 1. Рис.: 2. Бібліогр.: 17.
\end{abstract}

Ключові слова: конкурентоспроможність; виробництво молока; рейтингова оцінка; самозабезпеченість; регіон.

( ) О.А. Козак, О.Ю. Грищенко, 2020 